\title{
PENDIDIKAN KEAKSARAAN UNTUK MENCERDASKAN KEHIDUPAN MASYARAKAT
}

\author{
Sodiq A. Kuntoro*
}

\begin{abstract}
Literacy/illiteracy is not a simple matter. It does not only show whether a person can read and write words and letters, but also whether a person can face complicated problems of human life. Illiterate persons usually have weaknesses in understanding their own problems comprehensively. They suffer from an inferiority state of mind. They usually feel less important than others as they are unable to solve their own problems.

Literacy education for youths and adults as a movement to improve the human life condition, therefore, should not be understood in a technical level i.e. teaching reading and writing letters and words. Words are not empty. Words represent human thought about world and reality. They also represent the users' desire to do something. So, literacy education for youths and adults must be designed to improve the learners' cognition, and to develop a new perspective of self-consciousness in relation to the willingness to cope with the learners' life problems. The youths and adults learning activities must be based on transformative perspective, as they have been involved in the social development. The learning activities must transform them to be active participants or agents in the social development. Literacy education indeed must be considered in a wider understanding and not in a simple one.
\end{abstract}

Keywords: literacy education, youths and adults, cognition, development of human life condition.

\section{PENDAHULUAN}

Buta aksara bukan sekedar permasalahan yang sempit, yaitu ketidakmampuan individu atau warga masyarakat membaca atau menulis huruf atau katakata, tetapi secara luas terkait dengan ketidakmampuan untuk memahami, menganalisis, dan memecahkan permasalahan kehidupan. Kemampuan membaca-menulis yang benar bukan merupakan kemampuan mekanis, tetapi terkait dengan kemampuan intelektual yang dapat digunakan untuk memperluas pengetahuan, mengembangkan nilai-nilai dan sikap, mengembangkan keterampilan dan perilaku. Membaca suatu kata-kata (buku teks) sebenarnya bukan terpisah dari pemahaman tentang realita kehidupan, sebab katakata yang ditulis oleh manusia bukan kata-kata yang kosong, yang terlepas dari permasalahan, pemikiran, cita-cita, atau harapan yang berkembang dalam pikirannya. Kata-kata (words) adalah merupakan simbol-simbol pemahaman dan pemikiran manusia tentang realita (dunia) yang ada di sekitar dan katakata juga merupakan cerminan keinginan untuk melakukan tindakan.

Membaca kata-kata tanpa memahami makna yang terkandung di dalamnya maka menjadikan kegiatan membaca sebagai verbalistik, yang tidak memiliki dampak bagi perubahan atau pengembangan

\footnotetext{
* Dosen Universitas Negeri Yogyakarta
}

pemikiran, sikap, nilai-nilai, dan perilakunya. Keadaan semacam ini tentu tidak mencerdaskan individu atau warga masyarakat, tetapi mungkin sekedar memberikan label-label semu pada individu atau warga masyarakat bahwa mereka sudah bebas buta aksara, atau dengan mudah dapat kembali lagi menjadi buta aksara. Membaca adalah berfikir dan karena itu memberikan kekayaan akan pemahaman mengenai kehidupan, yang membantu seseorang dapat menyadari permasalahan kehidupan.

Kegiatan pemberantasan buta aksara bukan semata-mata bersifat teknis, tetapi lebih luas dari itu terkait dengan persoalan perubahan kesadaran dan pemikiran serta tindakan untuk melakukan perubahan. Apabila kegiatan pemberantasan buta aksara hanya didekati dan dilakukan secara teknis maka kemungkinan yang terjadi adalah sekedar tercapainya target-target kuantitatif yang tidak memiliki dampak pada perubahan kualitatif pada individu atau kelompok masyarakat penyandang buta aksara. Seolah-olah secara kuantitatif masyarakat sudah mencapai target pemberantasan buta aksara, tetapi secara kualitatif tidak terjadi perubahan pemikiran, sikap, nilai-nilai, dan perilaku individu atau kelompok masyarakat. Dalam keadaan semacam ini kemampuan membaca menulis tidak membangun perubahan pemikiran, sehingga kemungkinan sangat kecil untuk dapat digunakan Jurnal IImiah VISI PTK-PNF - Vol. 2, No.1 - $2007 \quad 23$ 
sebagai alat memperluas pengetahuan atau mengembangkan kemampuan berpikir dan pemecahan masalah kehidupan. Kegiatan pemberantasan buta aksara semacam itu tidak dapat mencerdaskan kehidupan masyarakat.

Strategi percepatan pemberantasan buta aksara melibatkan pilihan tentang model pembelajaran yang tepat, atau yang efisien dan efektif dalam mengajarkan membaca-menulis bagi tujuan untuk membangun kesadaran, meningkatkan kemampuan menganalisis problem kehidupan, dan tindakan memperbaiki kehidupan. Model pembelajaran seperti apakah yang tepat digunakan untuk mengajarkan membaca-menulis bagi individu atau kelompok masyarakat yang buta aksara yang dapat mencerdaskan kehidupan mereka. Begitu juga pemberantasan buta aksara melibatkan pilihan tentang kurikulum, materi pembelajaran, atau tema-tema pembelajaran. Apakah materi pembelajaran seperti sekolah formal yang berpusat pada mata pelajaran (matematika, bahasa Indonesia, ilmu sosial, dll.) cocok bagi pendidikan melek aksara (literacy- education)? Apakah materi pembelajaran lebih baik bersifat tematik yang memungkinkan pendekatan integratif dari bermacam-macam ilmu pengetahuan bagi pemecahan permasalahan kehidupan? Bagaimanakah sumber belajar yang digunakan dalam proses pembelajaran? Apakah menggunakan buku dan guru sebagai sumber utama pembelajaran atau menggunakan pengalaman yang dialami warga masyarakat dalam kehidupan sehari-hari sebagai sumber utama pembelajaran? Bagaimanakah peran pendidik (tutor/fasilitator) dalam pendidikan keaksaraan? Apakah mereka berperan sebagai pemberi pengetahuan? Atau mereka berperan sebagai pembimbing bagi warga belajar melakukan eksplorasi dan memahami tentang permasalahan kehidupan dan menemukan cara pemecahannya?

Tulisan ini bermaksud membahas permasalahan di atas dengan suatu konsep pemikiran: pendidikan keaksaraan, untuk mencerdaskan kehidupan masyarakat.

\section{PEMBAHASAN}

Pelaksanaan pemberantasan buta aksara bagi pemuda dan orang dewasa masih banyak mengalami kelemahan dalam aspek akademis dan metodologis. Kegiatan pemberantasan buta aksara bagi sasaran individu dan kelompok masyarakat yang memiliki situasi kehidupan yang khas (seperti mereka yang kurang mampu, dan mengalami keterbelakangan) sering dilakukan dengan pendekatan yang tidak tepat. Masih sering terjadi model pendidikan bagi anak-anak di sekolah diaplikasikan oleh tutor (fasilitator) dalam pendidikan keaksaraan bagi pemuda dan orang dewasa. Teknik-teknik didaktis-pedagogis masih banyak digunakan sehingga peserta pendidikan pemuda dan orang dewasa diperlakukan seperti anak-anak yang tidak memiliki keterlibatan dalam pemecahan masalah kehidupan. Kegiatan belajar membaca-menulis bagi orang dewasa sering dilakukan secara teknis-mekanis sekedar mengajarkan membaca-menulis kata-kata yang tidak memiliki makna keterkaitan dengan situasi khusus yang dihadapi kelompok masyarakatnya. Kegiatan membaca-menulis yang mereka lakukan kurang memiliki makna bagi individu dan kelompok masyarakat, karena isi pelajaran yang mereka terima tidak terkait dengan konteks sosial kehidupan yang mereka hadapi. Substansi pelajaran keaksaraan seperti menuliskan "Ini baju Ali”, "Baju Ali satu”, dan lain-lain kurang dapat mencerminkan makna spesifik bagi peserta belajar karena terlepas dari konteks kehidupan peserta belajar.

Kegiatan keaksaraan semacam itu sering kurang menarik bagi peserta belajar, dimana motivasi belajarnya sangat rendah. Mereka kurang terdorong secara sukarela untuk aktif mengikuti program pendidikan keaksaraan. Banyak alasan yang disampaikan peserta belajar untuk menyatakan keberatannya, misalnya: alasan anaknya belum tidur dan tidak dapat ditinggal pergi, masih melaksanakan tugas di dapur untuk menyiapkan nasi bagi keluarganya, tidak ada orang lain yang menunggu rumah jika mereka harus pergi belajar, masih sibuk mengusahakan kegiatan mata pencaharian. Ini semua sebenarnya merupakan bentuk rasionalisasi dari sikap keengganan atau kurang berminat untuk mengikuti program pendidikan keaksaraan.

Permasalahannya bukan semata-mata terletak pada peserta belajar (seperti halnya anak-anak yang sering tidak masuk sekolah), tetapi terletak pada isi program dan metode pembelajarannya. Teori belajar orang dewasa (andragogy) mengajarkan bahwa orang dewasa tertarik untuk belajar apabila program belajar itu dapat memenuhi kebutuhan dan minatnya. Minat dan kebutuhan belajar peserta belajar adalah merupakan titik awal dari aktivitas pengorganisasian belajar orang dewasa (Knowles, 1979). Hal ini mengisyaratkan bahwa 
dalam pengembangan program keaksaraan maka kebutuhan dan minat peserta belajar (warga masyarakat) harus dijadikan dasar bagi pengembangan kurikulum (program). Akan tetapi karena adanya tuntutan percepatan pelaksanaan pemberantasan buta aksara dan ketidakpahaman tentang metode pendidikan orang dewasa, maka para penyelenggara dan tutor (fasilitator) sering mengambil jalan pintas dalam melaksanakannya sekedar berpusat pada buku dan guru seperti yang dilakukan di sekolah.

Kegagalan dalam mengembangkan kurikulum pendidikan keaksaraan ini sebenarnya yang menjadi salah satu penyebab kurang menariknya program itu bagi peserta belajar. Teori belajar orang dewasa juga mengajarkan bahwa orientasi belajar orang dewasa adalah berpusat pada kehidupan. Oleh karena itu, kurikulum yang tepat bagi belajar orang dewasa adalah sesuai dengan situasi kehidupan, yaitu situasi kehidupan yang dihadapi oleh peserta belajar (Knowles, 1979). Permasalahan kehidupan yang dihadapi warga belajar baik secara individu maupun kelompok masyarakat adalah merupakan tema-tema pokok kehidupan yang dapat dijadikan sebagai tema-tema kurikulum dalam pendidikan keaksaraan. Buku dan guru harus menyesuaikan pada tema-tema pokok kehidupan yang dijadikan pembahasan dalam kegiatan belajar. Peserta belajar akan menjadi tertarik pada aktivitas belajar, apabila yang dipelajari bermanfaat bagi pemecahan permasalahan kehidupan, sebab pada dasamya hal itu merupakan kebutuhan mereka.

Pengelola program dan tutor (fasilitator) harus menyadari bahwa tugas pengembangan kurikulum pendidikan keaksaraan tidak dapat sekedar mengandalkan pada buku paket yang mungkin telah tersedia. Buku-buku paket mungkin tidak terlalu bermanfaat bagi peserta belajar, apabila buku paket tersebut tidak sesuai dengan permasalahan kehidupan yang secara nyata dihadapi kelompok masyarakatnya. Buku teks akan lebih tepat apabila berfungsi sebagai pelengkap yang bersifat memperkaya pemahaman tentang realita kehidupan yang secara nyata dihadapi oleh kelompok masyarakat. Kesadaran akan hal ini, mungkin masih belum berkembang secara meluas dilingkungan pengelola program maupun tutor pendidikan keaksaraan. Tampaknya masih dibutuhkan kegiatan kepelatihan yang berkesinambungan bagi pengelola program dan tutor untuk mengembangkan kesadaran dan kemampuan mengembangkan kurikulum yang berbasis pada permasalahan dan kebutuhan kelompok masyarakat yang menjadi target sasaran.

Praktik yang perlu ditinjau kembali adalah kurikulum program keaksaraan fungsional yang selama ini digunakan untuk meningkatkan pengetahuan membaca, menulis, dan berhitung dikaitkan dengan keterampilan fungsional yang sempit untuk meningkatkan taraf hidup peserta didik. Tujuan program keaksaraan fungsional ini tampaknya sudah tepat yaitu mengaitkan kemampuan membaca, menulis, dan berhitung dengan kemampuan praktis dalam mengembangkan kehidupan. Tetapi, menurut pendapat saya, terdapat keterkaitan yang terlalu sempit seolah-olah banyak dipaksakan pada keterampilan praktis yang berorientasi ekonomi semata yaitu peningkatan pedapatan peserta belajar. Sedangkan keterkaitan program keaksaraan bagi pengembangan keadaan sosial dan fisik kelompok masyarakatnya kurang memperoleh perhatian. Bukankah ketertiban dan stabilitas sosial budaya juga mempunyai arti penting sebagai modal sosial bagi kemajuan suatu masyarakat? Begitu juga peningkatan kondisi pisik masyarakat juga sangat dibutuhkan dalam kehidupan masyarakat.

Masyarakat kita masih membutuhkan penguatan stabilitas dan ketertiban sosial budaya sebagai alat untuk menciptakan kehidupan yang lebih tertib, teratur, dan disiplin, serta untuk mengurangi adanya konflik yang menghancurkan kehidupan bersama. Orientasi terlalu sempit pada keterampilan untuk peningkatan pendapatan berdampak negatif yaitu terbentuknya karakter yang sempit sekedar mencari uang dan melupakan aspek sosial budaya bagi ketertiban, dan kehidupan bersama. Oleh karena itu, keterkaitan program keaksaraan fungsional dengan pemecahan permasalahan kehidupan perlu diperluas mencakup permasalahan sosial, budaya, fisik, mental keagamaan, di samping permasalahan ekonomi.

Satu permasalahan penting dalam penyelenggaraan pendidikan keaksaraan adalah aspek metodologis. Metode pembelajaran dalam program pendidikan keaksaraan sering tampak bersifat mekanis yang kering. Pendidikan membaca, menulis, dan berhitung kurang terkait dengan pengembangan kemampuan peserta didik dalam menganalisis, dan 
memecahkan permasalahan yang dihadapi oleh kelompok masyarakat. Mungkin terdapat pertanyaan: Bagaimana mengaitkan kegiatan belajar membacamenulis dengan kemampuan peserta didik dalam memahami kehidupan? Mana yang sebaiknya didahulukan antara membahas dan mendiskusikan permasalahan masyarakat yang menjadi tema-tema pembelajaran untuk dipahami, dan dicari pemecahannya dengan pelajaran membaca-menulis yang ditujukan untuk peningkatan kemampuan membaca-menulis secara bermakna?

Dalam teori belajar orang dewasa juga ditekankan bahwa pengalaman adalah sumber yang paling kaya bagi belajar orang dewasa, dan metodologi utama pendidikan orang dewasa adalah menganalisis pengalaman (Knowles, 1979). Agar kegiatan belajar menjadi lebih menarik dan bermakna bagi kehidupan menurut pendapat saya, membangun pemahaman tentang permasalahan kehidupan yang dihadapi kelompok masyarakat, melalui kegiatan diskusi atau refleksi pengalaman-pengalaman peserta didik, adalah merupakan langkah pertama. Langkah ini merupakan upaya mengembangkan kognisi (pemahaman) tentang realita kehidupan yang secara spesifik menjadi situasi yang bermakna bagi kehidupan peserta didik. Kesadaran dan pemahaman baru diharapkan akan terbentuk, dan peserta didik tumbuh keinginan untuk melakukan perubahan terhadap kondisi kehidupan yang dirasakan kurang baik.

Diskusi tema-tema permasalahan kehidupan dengan menggunakan pengalaman subjektif yang dialami dalam kehidupan sehari-hari, akan menjadi suatu proses kognisi yaitu pengembangan intelektual dan keterlibatan emosional peserta didik. Kegiatan membaca yang melibatkan aktivitas berfikir tentang permasalahan kehidupan dapat meningkatkan kemampuan mengembangkan pengetahuan, ikatan kerjasama dalam memecahkan persoalan kehidupan, harga diri, dan kemampuan bahasa (menyampaikan pemikirannya). Permasalahan kehidupan seperti: lingkungan hidup, kesehatan, kebersihan, dan keindahan rumah, dll., adalah secara umum dapat diketemukan dalam setiap kelompok masyarakat, dan ini dapat dijadikan substansi diskusi (materi pembelajaran).

Langkah yang penting dilakukan selanjutnya adalah proses belajar membaca-menulis itu sendiri. Agar belajar membaca dan menulis itu memiliki makna bagi pemahaman kehidupan, maka apa yang diajarkan untuk dibaca dan ditulis bukan sesuatu yang terpisah dari tema-tema diskusi yang telah dilakukan. Apabila tema diskusi mereka tentang rumah sehat misalnya maka peserta belajar dihadapkan dengan bacaan tentang rumah sehat atau kondisi rumah yang ada dalam situasi kehidupan kelompok masyarakat mereka sendiri. Dengan demikian, tidak terjadi aktivitas membaca yang verbalistik, sebaliknya terjadi aktivitas membaca yang membangun kesadaran dan pemikiran terhadap realitas kehidupan mereka sendiri. Kegiatan pendidikan keaksaraan bagi pemuda dan orang dewasa yang mengkaitkan dengan pemahaman tentang realita kehidupan yang secara nyata dihadapi masyarakat akan dapat mencerdaskan kehidupan.

Sesuai dengan uraian di atas mutu pendidikan keaksaraan adalah terletak pada kebermaknaan pendidikan keaksaraan tersebut bagi perubahan kehidupan peserta didik dan kelompok masyarakatnya. Pendidikan keaksaraan yang sekedar mengajar membaca huruf atau kata-kata yang verbalistik dan tidak memiliki keterkaitan dengan pemahaman realitas kehidupan dapat dikatakan sebagai kegiatan yang kurang bermutu. Kemampuan membaca dan menulis yang verbalistik, kurang memberikan kontribusi pada peningkatan kecerdasan (intelektual) peserta didik karena kekuatan kecerdasan adalah terkait dengan kemampuan memahami permasalahan kehidupan dan menemukan ide-ide bagi pemecahan masalah tersebut.

Bagi orang dewasa pendidikan lebih dipandang sebagai kegiatan transformatif (perubahan) baik perubahan kognitif (Mezirow, dalam Sharan B. Merriam, 2001) maupun perubahan kesadaran diri yang mendorong pada pemberdayaan (Freire, 1977) dimana peserta didik dapat melihat dirinya dan kehidupannya dengan perspektif baru. Manusia yang tenggelam pada kesadaran fatalistik dan tenggelam pada pemikiran lama cenderung mengalami ketidakberdayaan dalam melakukan atau pembebasan dari keterbelengguan kehidupan. Untuk dapat melepaskan dari keterbelengguan kehidupan dibutuhkan perubahan struktur kognitif dan kesadaran baru, tetapi untuk dapat membangun perspektif baru dan kesadaran baru dalam memandang kehidupan dirinya dibutuhkan suatu aktivitas interpretasi dan reinterpretasi persepsi lama yang sudah dimiliki.

Pendidikan keaksaraan bagi orang dewasa agar dapat membangun perubahan kognitif dan kesadaran baru yang mendorong aktivitas melakukan perubahan kehidupan dibutuhkan aktivitas interpretasi dan reinterpretasi terhadap persepsi lama. Menghadapkan peserta didik dengan permasalahan kehidupan dan menampilkan gambar-gambar realitas kehidupan yang membutuhkan pemecahan merupakan suatu cara untuk mendorong interpretasi reinterpretasi persepsi lama. 
Oleh karena itu, bagi pengelola dan fasilitator pendidikan keaksaraan bagi pemuda dan orang dewasa dituntut untuk dapat menyusun tema-tema kehidupan yang dapat dijadikan bahan materi bagi kegiatan interpretasi dan reinterpretasi persepsi lama. Tematema kehidupan ini adalah merupakan permasalahan nyata yang dihadapi peserta didik dan kelompok masyarakatnya. Sehingga untuk menemukan tematema ini membutuhkan kegiatan penelitian atau identifikasi yang dilakukan oleh pendidik dan peserta didik.

Aktivitas diskusi kelompok untuk membicarakan dan menganalisis tema-tema kehidupan adalah merupakan metode yang tepat untuk dapat peserta didik membangun perubahan kognitif dan kesadaran. Dengan dibantu oleh penampilan gambar-gambar yang relevan dengan tema-tema kehidupan itu peserta didik akan lebih mudah untuk proses analisis realita kehidupan yang dihadapi.

Proses pendidikan keaksaraan bagi pemuda dan orang dewasa yang bermutu adalah apabila proses pendidikan tersebut melibatkan proses mendiskusikan dan merefleksikan pikiran dan perasaan yang terkait dengan tema-tema kehidupan yang menjadi sasaran pemecahan. Proses analisis masalah dan menemukan perspektif pemikiran baru, dan kesadaran perlunya tindakan untuk memperbaiki keadaan hidup adalah proses transformasi yang penting bagi pencerdasan kehidupan masyarakat.

\section{KESIMPULAN}

Dalam kegiatan pemberantasan buta aksara hendaknya tidak dilakukan secara teknis mekanis, yaitu sekedar mengajar membaca menulis kata-kata atau huruf-huruf secara verbalistik yang tidak memiliki makna bagi pemahaman terhadap realita kehidupan bagi peserta didik. Buta aksara bukan sekedar permasalahan sempit, yaitu ketidakmampuan individu atau warga masyarakat membaca atau menulis huruf atau kata-kata, tetapi secara luas terkait dengan ketidakmampuan untuk memahami, menganalisis, dan memecahkan permasalahan kehidupan. Apabila pelaksanaan kegiatan pendidikan keaksaraan yang ditujukan bagi pemuda dan orang dewasa dilakukan sekedar mengajar membaca dan menulis tanpa mengaitkan dengan aktivitas pemahaman tentang permasalahan atau realita kehidupan maka kegiatan pendidikan keaksaraan tersebut tidak dapat mencerdaskan kehidupan masyarakat.

Pemuda dan orang dewasa yang menjadi sasaran program pemberantasan buta aksara adalah memiliki karakteristik tersendiri yang secara umum mereka sudah memiliki peran sosial dalam kehidupan. Mereka sudah terlibat dalam kegiatan mencari nafkah, bekerja untuk memenuhi keutuhan keluarga dan dirinya, memiliki tanggungjawab untuk terlibat dalam pemecahan permasalahan kehidupan masyarakatnya. Dalam kondisi semacam ini mereka akan tertarik pada kegiatan belajar apabila kegiatan belajar tersebut terkait dengan peningkatan kemampuan dalam melaksanakan peran sosialnya.

Mutu pendidikan keaksaraan bagi pemuda dan orang dewasa adalah terletak pada kebermaknaan pendidikan keaksaraan tersebut bagi perubahan kehidupan peserta didik dan masyarakatnya. Bagi orang dewasa pendidikan lebih dipandang sebagai kegiatan transformatif (perubahan) baik perubahan kognitif, maupun perubahan kesadaran diri yang mendorong pada pemberdayaan, dimana peserta didik dapat melihat dirinya dan kehidupannya dengan persperktif baru. Untuk dapat melepaskan diri dari keterbelengguan kehidupan dibutuhkan perubahan struktur kognitif dan kesadaran baru agar masyarakat memiliki kemauan dan kemampuan untuk melakukan perubahan kehidupan. Oleh karena itu, proses pendidikan keaksaraan bagi pemuda dan orang dewasa yang bermutu adalah pabila proses pendidikan tersebut melibatkan proses mendiskusikan dan merefleksikan permasalahan kehidupan untuk menemukan perspektif pemikiran baru dan kesadaran perlunya tindakan untuk memperbaiki kondisi hidup.

\section{DAFTAR PUSTAKA}

Freire, P. (1977). Pedagogy of the oppressed. Auckland: Penguin Books Ltd.

Knowles, M. (1979). The adult learner: A neglected species (2nd ed.). Houston: Gulf Publishing Company.
Merriam, S. B. (2001). The new update on adult learning theory. San Francisco: Jossey Bass. 